\title{
Proteomic analysis of human osteoarthritis synovial fluid
}

\author{
Lavanya Balakrishnan ${ }^{1,2}$, Raja Sekhar Nirujogi ${ }^{1,3}$, Sartaj Ahmad ${ }^{1,4}$, Mitali Bhattacharjee ${ }^{1,5}$, Srikanth S Manda ${ }^{1,3}$, \\ Santosh Renuse ${ }^{1,5}$, Dhanashree S Kelkar ${ }^{1,5}$, Yashwanth Subbannayya ${ }^{1,6}$, Rajesh Raju', Renu Goel ${ }^{1,2}$, \\ Joji Kurian Thomas, ${ }^{1,5}$, Navjyot Kaur ${ }^{7}$, Mukesh Dhillon? ${ }^{7}$, Shantal Gupta Tankala ${ }^{7}$, Ramesh Jois ${ }^{8}$, Vivek Vasdev ${ }^{9}$, \\ YL Ramachandra², Nandini A Sahasrabuddhe ${ }^{1}$, TS Keshava Prasad ${ }^{1,3,4}$, Sujatha Mohan ${ }^{10}$, Harsha Gowda', \\ Subramanian Shankar ${ }^{7 *}$ and Akhilesh Pandey ${ }^{11,12,13,14^{*}}$
}

\begin{abstract}
Background: Osteoarthritis is a chronic musculoskeletal disorder characterized mainly by progressive degradation of the hyaline cartilage. Patients with osteoarthritis often postpone seeking medical help, which results in the diagnosis being made at an advanced stage of cartilage destruction. Sustained efforts are needed to identify specific markers that might help in early diagnosis, monitoring disease progression and in improving therapeutic outcomes. We employed a multipronged proteomic approach, which included multiple fractionation strategies followed by high resolution mass spectrometry analysis to explore the proteome of synovial fluid obtained from osteoarthritis patients. In addition to the total proteome, we also enriched glycoproteins from synovial fluid using lectin affinity chromatography.

Results: We identified 677 proteins from synovial fluid of patients with osteoarthritis of which 545 proteins have not been previously reported. These novel proteins included ADAM-like decysin 1 (ADAMDEC1), alanyl (membrane) aminopeptidase (ANPEP), CD84, fibulin 1 (FBLN1), matrix remodelling associated 5 (MXRA5), secreted phosphoprotein 2 (SPP2) and spondin 2 (SPON2). We identified 300 proteins using lectin affinity chromatography, including the glycoproteins afamin (AFM), attractin (ATRN), fibrillin 1 (FBN1), transferrin (TF), tissue inhibitor of metalloproteinase 1 (TIMP1) and vasorin (VSN). Gene ontology analysis confirmed that a majority of the identified proteins were extracellular and are mostly involved in cell communication and signaling. We also confirmed the expression of ANPEP, dickkopf WNT signaling pathway inhibitor 3 (DKK3) and osteoglycin (OGN) by multiple reaction monitoring (MRM) analysis of osteoarthritis synovial fluid samples.

Conclusions: We present an in-depth analysis of the synovial fluid proteome from patients with osteoarthritis. We believe that the catalog of proteins generated in this study will further enhance our knowledge regarding the pathophysiology of osteoarthritis and should assist in identifying better biomarkers for early diagnosis.
\end{abstract}

Keywords: Body fluid, Cartilage, Joint destruction, Glycosylation

\section{Background}

Osteoarthritis $(\mathrm{OA})$ is a degenerative joint disorder characterized by articular cartilage damage, formation of osteophytes and subchondral bone cysts, thickened subchondral plate, inflammation and neovascularisation of synovial membrane [1]. OA is one of the leading causes

\footnotetext{
*Correspondence: shankarsid@gmail.com; pandey@jhmi.edu

${ }^{7}$ Department of Internal Medicine, Armed Forces Medical College, Pune,

Maharashtra 411040, India

${ }^{11}$ McKusick-Nathans Institute of Genetic Medicine, Johns Hopkins University,

733 N. Broadway, BRB 527, Baltimore, MD 21205, USA

Full list of author information is available at the end of the article
}

of disability among the aging population. The two important risk factors for developing OA are obesity and age [2]. Despite the high prevalence of OA, its mechanism of pathogenesis still remains unclear [3]. The diagnosis of OA can be made based on structural abnormalities or symptoms resulting from these abnormalities. While OA is evident radiologically in most of the elderly population, only $10 \%$ are symptomatic and exhibit a measurable limitation of function. Further, radiographs may be normal in early disease owing to lack of sensitivity in visualizing minimal cartilage loss [4]. Thus, the

\section{Biomed Central}


diagnostic tools that are currently in use have their own limitations and provide an inaccurate assessment of disease progression [5]. Finally, the drugs currently used for the treatment of $\mathrm{OA}$ are aimed at reducing pain and do not possess any disease modifying activity [6].

Studying the synovial fluid proteome should yield a higher concentration of potential biomarkers than serum or plasma, as the synovial fluid is in direct physical contact with the synovium, ligament, meniscus, joint capsule and bone [7]. Alterations in the structure and metabolism of any of these tissues during disease should be reflected as alterations in the composition of the synovial fluid proteome. Therefore, the synovial fluid proteome has the potential to indicate the severity and progression of the disease [8]. Advances in proteomic technologies have facilitated extensive proteomic characterization of several body fluids [9-15]. A detailed molecular characterization of the synovial fluid could identify proteins associated with pathogenesis, which can be developed as markers for evaluation of the disease in early stages and its progression.

Yamagiwa et al. demonstrated a five-fold increase in the expression of 18 protein spots including haptoglobin among different synovial fluid samples from OA patients using 2-DE platform [16]. In another study, 135 proteins were identified from synovial fluid and 18 of them were shown to be differentially expressed in OA patients. Proteins identified to be elevated in OA included alpha 1- microglobulin, apolipoprotein E, complement component 3, haptoglobin, orosomucoid 1 and group specific component (vitamin D binding protein) [3]. A method of endogenous profiling of peptides from OA synovial fluid that resulted in identification of 40 proteins was described by Kamphorst et al. in 2007 [17]. In a recent study, abnormally high levels of complement components were shown in OA synovial fluid [18]. Sohn et al. identified 108 proteins from OA synovial fluid and found that only $36 \%$ of them were known to be in the plasma/serum [19]. Sixty six proteins, involved in acute phase response, complement and coagulation pathways were reported to be differentially expressed between healthy and OA synovial fluid in a recent study by Ritter et al [20]. A summary of previous proteomic studies on OA synovial fluid is provided in Table 1. Most of these investigations were carried out using low resolution mass spectrometers and with minimal fractionation of the samples, which limited the depth of coverage. In this study, we carried out a comprehensive cataloging of proteins from OA synovial fluid by including multiple fractionation methods followed by high resolution mass spectrometry analysis.

\section{Results and discussion}

\section{Identification of proteins from OA synovial fluid}

Synovial fluid from five OA patients was pooled and the abundant proteins were depleted using Human MARS-6 column. The resulting sample was then subjected to multiple fractionation methods - SDS-PAGE at the protein level and SCX and OFFGEL at the peptide level - to reduce the complexity of the sample. In addition, lectin enrichment strategy was employed to enrich glycoproteins using a mixture of three different lectins - wheat germ agglutinin, concanavalin A and jacalin. These lectins have different binding specificities and thereby permit enrichment of a broader coverage of glycoproteins. The lectin enriched fractions were subjected to SDS-PAGE and SCX fractionation. All of these fractions were analyzed on a Fourier transform LTQ-Orbitrap Velos mass spectrometer. The workflow illustrating the steps involved in the proteomic analysis of OA synovial fluid is shown in Figure 1.

124,380 peptide spectrum matches generated from the mass spectrometric analysis of 112 fractions of depleted and lectin-enriched OA synovial fluid resulted in the identification of 5,544 peptides corresponding to 677 proteins. The number of proteins identified from the depleted and lectin-enriched fractions are summarized in Additional file $1 \mathrm{~A}$ and $1 \mathrm{~B}$, respectively. Of the 300 lectin-enriched proteins identified, 171 proteins were already known to be glycosylated from the data available in Human Protein Reference Database (HPRD) [22,23]. The complete list of all proteins and peptides identified in our study are provided in Additional files 2 and 3, respectively. The relative abundance of the 25 most abundant proteins identified is provided in Additional file 4.

Table 1 A summary of proteomic studies published on healthy and osteoarthritis synovial fluid

\begin{tabular}{|c|c|c|c|c|c|}
\hline & $\begin{array}{l}\text { Synovial fluid used } \\
\text { (Healthy/Osteoarthritis) }\end{array}$ & Method & $\begin{array}{l}\text { Mass spectrometer } \\
\text { used }\end{array}$ & $\begin{array}{l}\text { Number of } \\
\text { proteins identified }\end{array}$ & Publication \\
\hline 1 & Healthy/Osteoarthritis & In-gel digestion & LCQ DECA XP & 135 & Gobezie, R et al., 2007 [3] \\
\hline 2 & Osteoarthritis & $\begin{array}{l}\text { Depletion of albumin \& lgG, IEF, } \\
\text { In-gel digestion }\end{array}$ & XCT Ultra lon trap & 108 & Sohn, DH et al., 2012 [19] \\
\hline 3 & Healthy/Osteoarthritis & 2D-DIGE & - & 66 & Ritter, SY et al., 2013 [20] \\
\hline 4 & Healthy/Osteoarthritis & Ultrafiltration and solid phase extraction & LTQ XL-Orbitrap & 40 & Kamphorst, JJ et al., 2007 [17] \\
\hline 5 & Osteoarthritis & Depletion of albumin \& lgG, 2-DE & - & 18 & Yamagiwa, H et al., 2003 [16] \\
\hline 6 & Healthy/Osteoarthritis & IEF, 2D-DIGE & - & 12 & Wang, Q et al., 2012 [18] \\
\hline 7 & Osteoarthritis & Protein chip array & SELDI-TOF-MS & 4 & de Seny, D et al., 2011 [21] \\
\hline
\end{tabular}




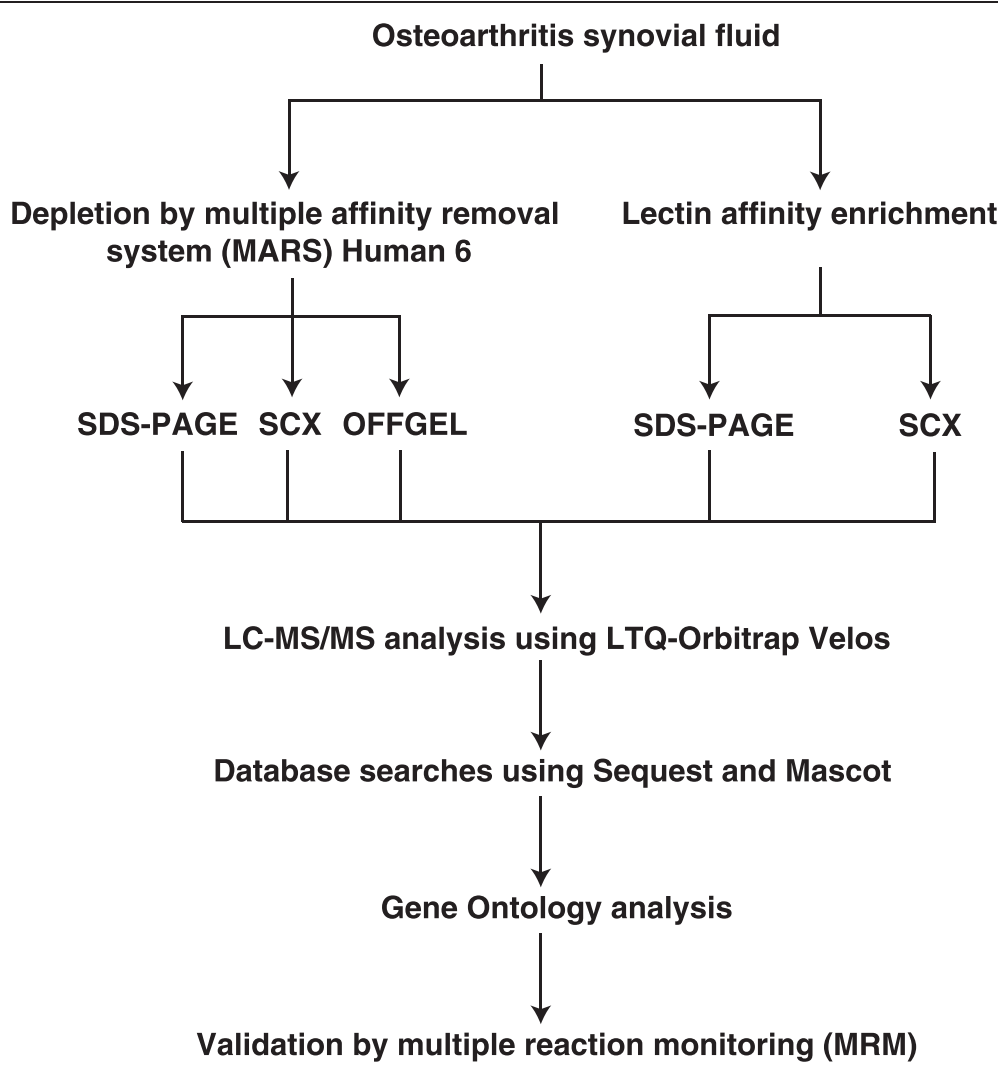

Figure 1 Work flow illustrating the steps involved in the proteomic analysis of OA synovial fluid. OA synovial fluid samples were pooled and subjected to depletion of abundant proteins by MARS-6 LC column and lectin affinity chromatography using three different lectins (Concanavalin A, wheat germ agglutinin and jacalin). The depleted fraction was then subjected to SDS-PAGE, SCX and OFFGEL fractionation. The lectin enriched fraction was subjected to SDS-PAGE analysis and SCX fractionation. All fractions were analyzed on LTQ-Orbitrap Velos mass spectrometer. Sequest and Mascot algorithms were used to perform database searches. Subsequently, gene ontology-based functional characterization of the identified synovial fluid proteins was carried out. Further, validation by MRM- based assays was carried out for three proteins identified from discovery studies.

\section{Classification based on gene ontology (GO) annotation}

GO-based annotation was used to categorize the proteins based on their subcellular localization, molecular function and biological processes. Signal peptide and transmembrane domain analysis of the identified proteins was done by using the domains/motif information available in HPRD. Out of 677 proteins, 400 proteins were found to have a signal peptide, 113 have transmembrane domains and 77 proteins possessed both. Classification-based on the subcellular localization (Figure 2A) indicated that $40 \%$ of proteins were extracellular. Proteins were also localized to cytoplasm (19\%), plasma membrane (16\%) and nucleus (10\%). Based on their molecular function (Figure 2B), proteins were classified as constituents of the extracellular matrix (12\%) or those involved in transporter activity (12\%), cell adhesion molecule activity (10\%), protease inhibitor activity (7\%) and complement activity (7\%). Biological process-based (Figure 2C) categorization showed that a majority of them played a role in cell communication and signaling (17\%), cell growth and/or maintenance (17\%), protein metabolism $(17 \%)$ and immune response (13\%).
Proteins previously reported in OA synovial fluid

Several proteins reported earlier in OA synovial fluid were identified in our study confirming the validity of the experimental approach employed by us. Collagen proteins provide the required strength and stiffness to the cartilage [24]. Several type I, III, V, and VI collagens (COL1A1, COL1A2, COL3A1, COL5A1, COL5A2 COL6A1 and COL6A3), aggrecan (ACAN), cartilage oligomeric protein (COMP), cartilage intermediate layer protein, matrix Gla protein, extracellular matrix protein 1 , lumican and vitronectin identified in this study were already reported in OA synovial fluid $[3,17]$. ACAN is the major proteoglycan that confers load bearing properties to the cartilage [25]. The levels of COMP and ACAN were found to be significantly elevated in the serum and synovial fluid of OA patients $[26,27]$ demonstrating its significance in OA pathogenesis. Xie et al. have shown an increased expression of fibronectin 1 (FN1) in the articular cartilage and synovial fluid of OA patients [28]. Matrix metalloproteinases (MMPs), MMP1 and MMP3 that were known to be involved in the degradation of extracellular matrix (ECM) of the cartilage were also identified in our study. Their levels were found 


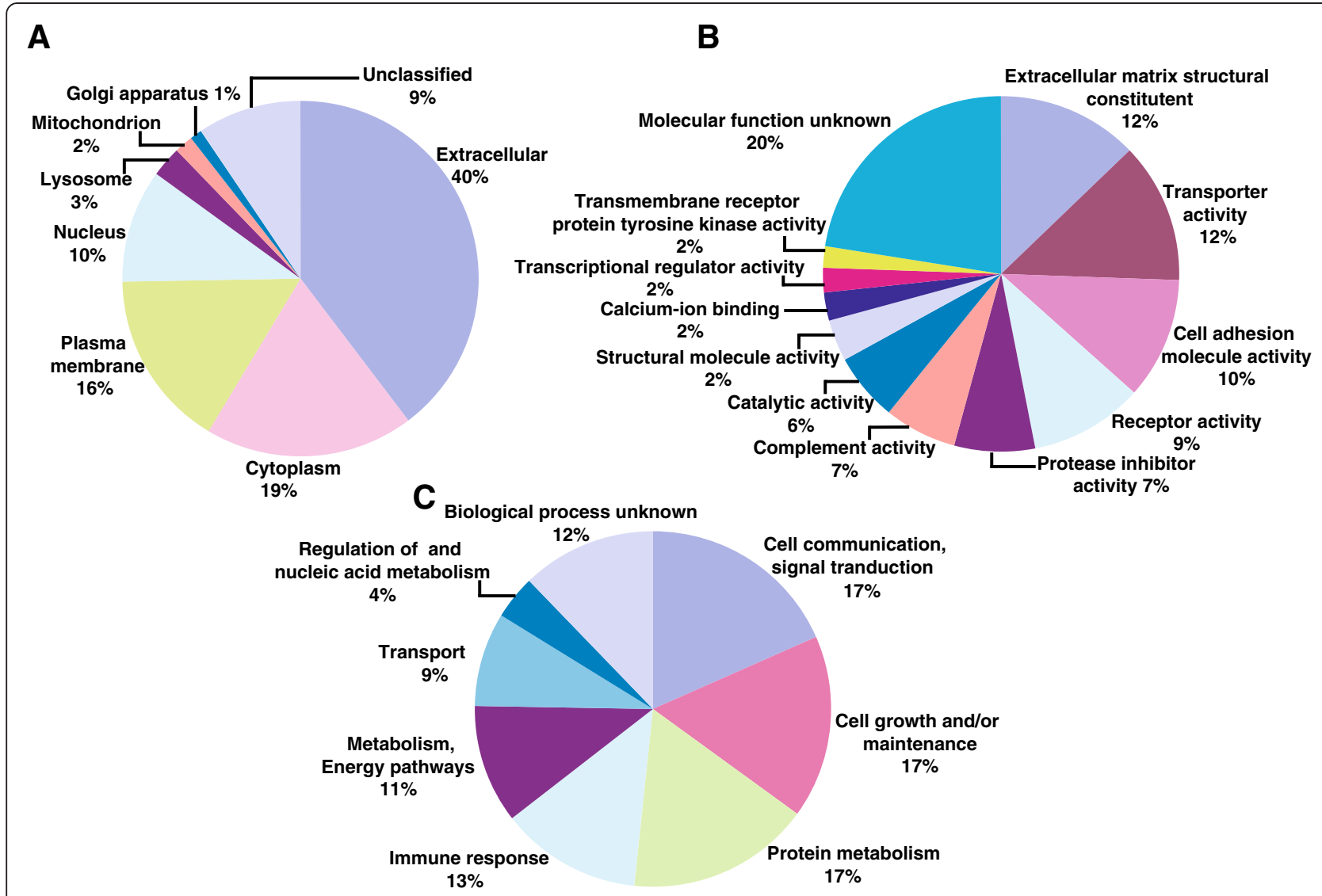

Figure 2 Gene Ontology based classification of proteins identified from OA synovial fluid. (A) Cellular component (B) Molecular function, and (C) Biological processes.

to be higher in the synovial fluid of primary $\mathrm{OA}$ and joint knee injury patients [29]. The presence of several serine protease inhibitors (SERPINs), SERPINA1, SERPINA3, SERPINA6, SERPINC1, SERPINF1, SERPING1 that regulated the proteases involved in the degradation of ECM were also confirmed in our study $[3,19]$. Various complement components ( $\mathrm{C} 2 \mathrm{C} 3, \mathrm{C} 4 \mathrm{~A}, \mathrm{C} 4 \mathrm{~B}, \mathrm{C} 5, \mathrm{C} 7$ and $\mathrm{C} 9)$ that have been shown to contribute to the inflammation in $\mathrm{OA}$ joints were also identified in this study [18]. The levels of the primary lubricating macromolecule in synovial fluid, proteoglycan 4 (PRG4) has also been reported to be higher in the synovial fluid samples of patients in the advanced stage of OA [30].

\section{Proteins not reported in OA synovial fluid}

Out of 677 proteins identified, 545 have not been reported earlier in OA synovial fluid. A partial list of novel proteins is provided in Table 2. Some of the novel molecules identified are discussed below. Representative MS/ MS spectra of peptides identified from the proteins, Nidogen 2 (NID2), Alanyl (membrane) aminopeptidase (ANPEP), Sushi, von Willebrand factor type A, EGF and pentraxin domain containing 1 (SVEP1) and Osteoglycin $(O G N)$ are shown in Figure 3.

\section{Extracellular matrix proteins}

Degradation of the articular cartilage is a hallmark of OA. Damage to the cartilage causes irreversible changes in the ECM that results in joint dysfunction [31]. Asporin (ASPN) is an ECM protein that belongs to the small leucine-rich proteoglycan family. Asporin was detected at higher levels in articular cartilage, subchondral bone and osteophytes of OA patients [32,33]. A recent study demonstrated that the expression of ASPN was highly regulated by the transcription factor, SP1 in the human articular chondrocytes [34]. Asporin has been shown to induce osteoblast-driven collagen mineralization [35]. Polymorphisms in the aspartic acid repeat of ASPN have been shown to be associated significantly with the susceptibility to OA [36]. Also, it has been shown to regulate chondrogenesis by inhibiting TGF-beta 1 mediated expression of genes, aggrecan $(A C A N)$ and type II collagen (COL2A1) in the cartilage [36,37]. NID2 is a basement membrane protein that has been shown to interact with collagen type I, IV, laminin-1 and perlecan present in the ECM [38]. Kreugel J et al., have shown that NID2 expression was increased in late-stage OA cartilage in humans and established its role in cartilage regeneration [39]. 
Table 2 A partial list of proteins previously not reported in OA synovial fluid

\begin{tabular}{|c|c|c|c|c|c|}
\hline & $\begin{array}{l}\text { Gene } \\
\text { symbol }\end{array}$ & Protein & Subcellular localization & Molecule class & Molecular function \\
\hline 1 & ADAMDEC1 & ADAM-like, decysin 1 & Extracellular & Metalloprotease & Metallopeptidase activity \\
\hline 2 & ANPEP & Alanyl (membrane) aminopeptidase & $\begin{array}{l}\text { Plasma membrane, } \\
\text { Extracellular }\end{array}$ & Metalloprotease & Metallopeptidase activity \\
\hline 3 & ASPN & Asporin & Extracellular & $\begin{array}{l}\text { Extracellular } \\
\text { matrix protein }\end{array}$ & $\begin{array}{l}\text { Extracellular matrix structural } \\
\text { constituent }\end{array}$ \\
\hline 4 & CD84 & CD84 antigen (leukocyte antigen) & Plasma membrane & Immunoglobulin & Cell adhesion molecule activity \\
\hline 5 & COLEC10 & Collectin sub-family member 10 (C-type lectin) & Cytoplasm & Unclassified & Molecular function unknown \\
\hline 6 & DKK3 & Dickkopf WNT signaling pathway inhibitor 3 & Extracellular, Cytoplasm & Ligand & Receptor and lipid binding \\
\hline 7 & MMRN2 & Multimerin 2 & Extracellular & $\begin{array}{l}\text { Extracellular } \\
\text { matrix protein }\end{array}$ & $\begin{array}{l}\text { Extracellular matrix structural } \\
\text { constituent }\end{array}$ \\
\hline 8 & SPARCL1 & SPARC-like 1 & Extracellular & Secreted polypeptide & Calcium ion binding \\
\hline 9 & THY1 & Thy- 1 cell surface antigen & Plasma membrane & $\begin{array}{l}\text { Integral membrane } \\
\text { protein }\end{array}$ & Protein binding \\
\hline 10 & VSIG4 & V-set and immunoglobulin domain containing 4 & $\begin{array}{l}\text { Plasma membrane, } \\
\text { Endosome }\end{array}$ & Complement receptor & Receptor activity \\
\hline
\end{tabular}

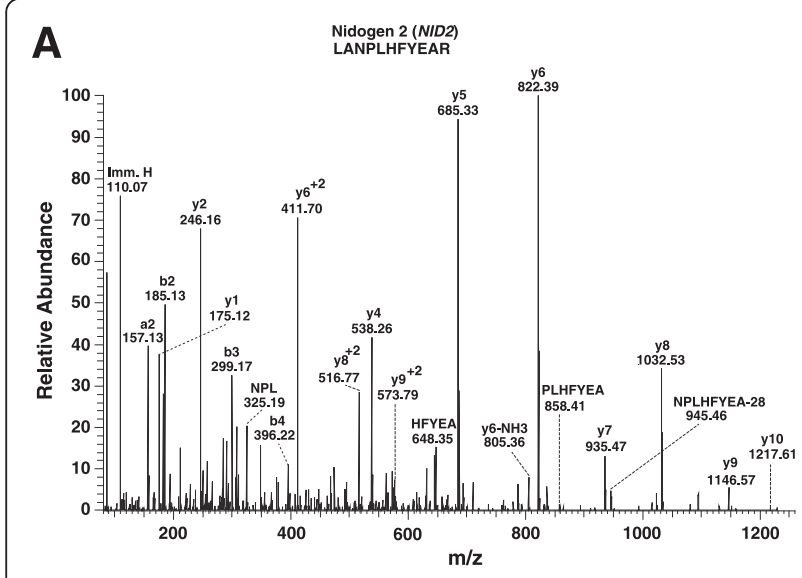

C Sushi, von Willebrand factor type A, EGF and pentraxin domain-containing protein 1 (SVEP1)

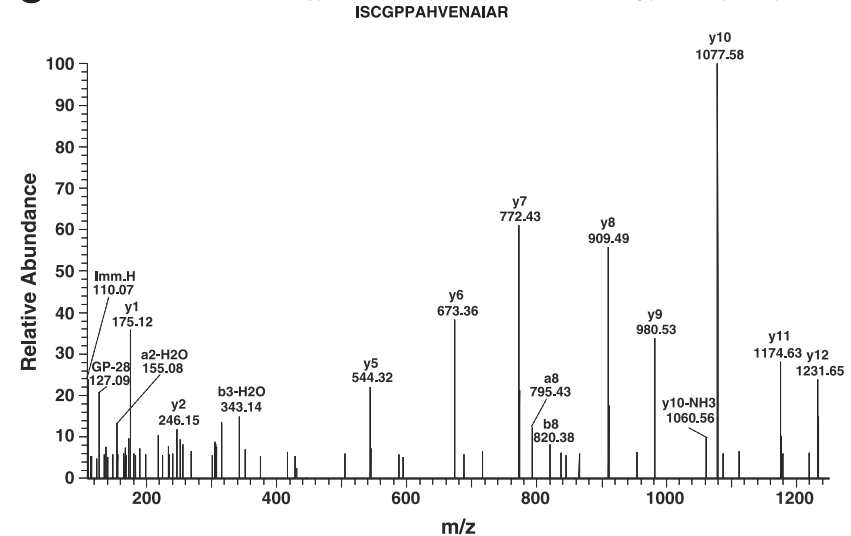

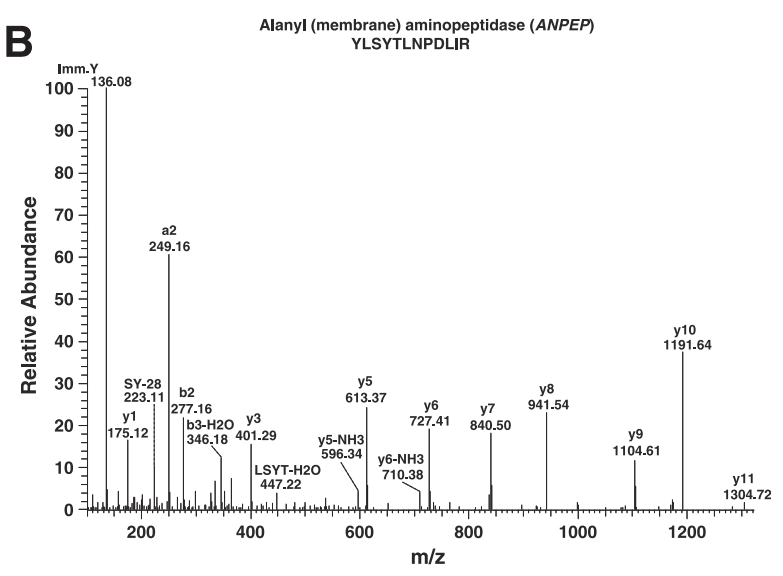

D Osteoglycin (OGN)

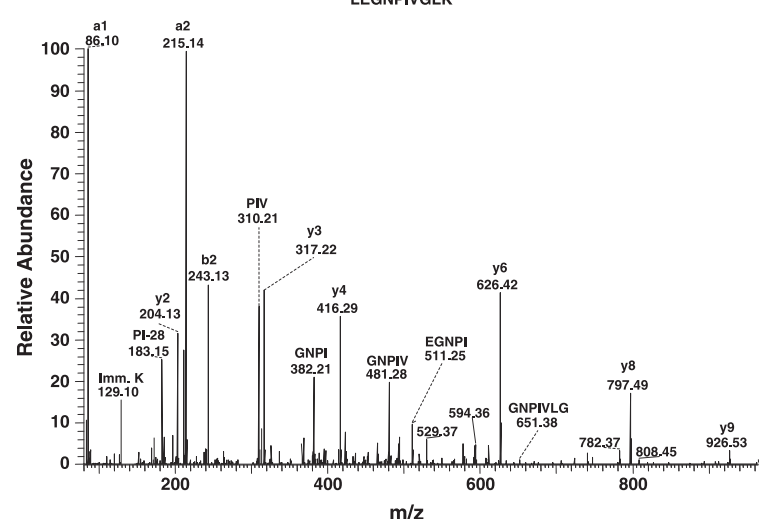

Figure 3 Representative MS/MS spectra of peptides from novel proteins identified from OA synovial fluid. (A) Nidogen 2 (NID2), (B) Alanyl (membrane) aminopeptidase (ANPEP), (C) Sushi, von Willebrand factor type A, EGF and pentraxin domain containing 1 (SVEP1) and (D) Osteoglycin (OGM). 


\section{Proteolytic enzymes and protease inhibitors}

Degradation of the ECM in OA synovial joint has been shown to be primarily catalyzed by the proteolytic enzymes. Alterations in the activities and expression levels of these enzymes and their associated inhibitors have been shown to disturb the balance between anabolism and catabolism in the affected joints [8]. Alanyl (membrane) aminopeptidase (ANPEP) is a membrane bound metalloprotease enzyme expressed on the surface of human normal and malignant myeloid cells, fibroblasts, hepatocytes and epithelial cells of the kidney and small intestine [40]. It has also been shown to be expressed by vascular endothelial cells and played a significant role in angiogenesis [41]. It has been suggested that simultaneous inhibition of ANPEP and dipeptidyl-peptidase 4 would provide an effective means of therapy against $\mathrm{T}$ cell mediated disorders including autoimmune diseases, inflammation and allergy [42]. Recent studies have speculated its role in inflammatory monocyte trafficking [43]. ADAM-like, decysin 1 (ADAMDEC1) is a recently identified member of the disintegrin metalloproteinase family. It is located on the metalloprotease gene cluster on chromosome 8p12 comprising of other proteases, $A D A M 7$ and $A D A M 28$ and was shown to have arisen as a result of partial gene duplication of a gene located at this locus [44]. Abundant expression of ADAMDEC1 has been reported in monocytes-derived macrophages and in colon tissue [45].

Secreted phosphoprotein 2 (SPP2) is a $24 \mathrm{kDa}$ secreted phosphoprotein initially cloned from bovine cortical bone. Northern blot analysis has shown SPP2 expression in bone and liver. Its protein sequence was found to be related to the cystatin family of thiol protease inhibitors suggesting a role in the regulation of thiol proteases involved in bone turnover [46]. Studies have also suggested a role for SPP2 in the inhibition of calcification [47] and bone morphogenetic protein 2 (BMP-2) induced bone formation $[48,49]$. Serpin peptidase inhibitor, clade I (pancpin), member 2 (SERPINI2) belongs to the serine protease inhibitor superfamily. Though the other members of this superfamily have already been shown to be associated with OA, SERPINI2 has not been implicated in OA.

\section{Cell adhesion molecules}

Cell-cell and cell-matrix interactions are mediated by cell adhesion molecules. These interactions are critical for the regulation of a plethora of biological processes including synovial inflammation and tissue remodelling [50]. Sushi, von Willebrand factor type A, EGF and pentraxin domain containing 1 (SVEP1) is a cell adhesion molecule, also known as selectin-like osteoblast derived protein. It was shown to be expressed in the skeletal cells of the bone and periosteum as well as by the stromal osteogenic cells [51]. The role of SVEP1 in mediating cell adhesion in an integrin $\alpha 9 \beta 1$ dependent manner has been reported recently [52]. Osteomodulin (OMD) is a keratan sulfate proteoglycan that promotes cell binding mediated by integrin alphaV beta3 in bone [53]. Osteomodulin was detected in bovine mature osteoblasts and human odontoblasts suggesting its role in bone mineralization [54]. Its expression was found to increase the differentiation and maturation of osteoblasts [55]. Microarray analysis has revealed the association of Osteomodulin in osteoblast differentiation mediated by bone morphogenetic protein 2 [56].

\section{Growth factors and cytokines}

Growth factors and cytokines are regulatory molecules that play a significant role in joint destruction and disease pathogenesis. Their levels are altered in case of joint injury or disease [8]. Osteoglycin (OGN), also known as mimecan or osteoinductive factor, belongs to the family of small leucine rich proteoglycans. Mice deficient in osteoglycin showed an increase in bone density [57]. In irradiated cultured osteoblasts, osteoglycin expression was elevated speculating its role in triggering the formation of bone along with other growth factors and matrix proteins [58]. Its expression was also increased in irradiated synovial membrane of rheumatoid arthritis patients [59]. Family with sequence similarity 3, member C (FAM3C) was characterized recently as a protein ubiquitously expressed in tissues with cytokine activity. It is also known as predicted-osteoblast protein, with no known function [60]. Polymorphisms in the FAM3C gene have been shown to be associated with bone mineral density and fore arm fracture [61,62].

\section{Glycoproteins in OA synovial fluid}

Glycosylation of proteins is a biologically significant and complex post-translational modification associated with membrane and secreted proteins. Body fluids are rich in glycoproteins and characterizing the glycoproteome can increase the dynamic range of protein identification in synovial fluid [63]. We identified several glycoproteins in OA synovial fluid by lectin affinity enrichment. The list of all the proteins identified by lectin enrichment has been provided in Additional file 5. Afamin (AFM) is a vitamin E binding glycoprotein that belongs to the albumin gene family [64]. It was found to be secreted from differentiated osteoblasts and stimulated the migration of osteoblastic lineages through the activation of Akt signaling pathway [65]. Its presence in OA synovial fluid has been demonstrated by many proteomic studies $[3,19]$. Tissue inhibitor of metalloproteinases 1 (TIMP1) is a glycoprotein known to be involved in the degradation of extracellular matrix in the cartilage. TIMP1 levels have been demonstrated to be higher in the synovial fluid of OA knees with effusion [66]. C-type lectin 
domain family 3, member B (CLEC3B), also known as tetranectin is a plasminogen kringle-4 binding glycoprotein [67]. CLEC3B was involved in bone formation and was expressed at higher levels in the articular cartilage of OA patients [68]. Periostin (POSTN), also known as osteoblast-specific factor is a vitamin K-dependent protein. Expression of periostin was also detected in the periosteum and extracellular matrix of the cartilage and meniscus [69]. The association of periostin with bone mineral density and vertebral fracture risk has been recently illustrated by Xiao et al. [70].

\section{Validation by multiple reaction monitoring (MRM)}

MRM analysis was employed to validate the expression of ANPEP, OGN and Dickkopf WNT signaling pathway inhibitor 3 (DKK3) in ten OA synovial fluid samples. These included the five samples that were used for the discovery phase LC-MS/MS analysis. ANPEP is a metalloprotease and OGN has growth factor activity and have been already described above. DKK3 is an antagonist of Wnt signaling pathway and its expression has been reported to be upregulated in the OA cartilage [71]. The proteotypic peptides selected for ANPEP were AQIINDAFNLASAHK $(\mathrm{z}=+2$, $\mathrm{m} / \mathrm{z}=806.93)$ and YLSYTLNPDLIR $(\mathrm{z}=+2,734.40)$. For OGN, the peptides targeted were DFADIPNLR $(\mathrm{z}=+2$, $\mathrm{m} / \mathrm{z}+530.77)$ and LEGNPIVLGK $(\mathrm{z}=+2, \mathrm{~m} / \mathrm{z}=520.31)$. For DKK3, DQDGEILLPR $(\mathrm{z}=+2, \mathrm{~m} / \mathrm{z}=578.30)$ was $\operatorname{tar}-$ geted (Table 3). The MRM results from these experiments show that the proteins are easily detected in all individual OA synovial fluid samples in agreement with LC-MS/MS data obtained from the pooled samples. The bar graphs representing the peak areas from triplicate runs for each protein are shown in Figure 4.

\section{Data availability}

The raw data obtained in this study were submitted to public data repositories, Human Proteinpedia (https://www. humanproteinpedia.org) and Tranche (https://www.proteomecommons.org/tranche/). Processed data and the database search results can be downloaded from Human Proteinpedia using HuPA_00698 code [72]. The following hash can be used to download the raw data from Tranche repository: jQquXSNp5ly3M7vOj66hnmxADXDp2DPU7B SyWzal5KdJPGKIxe6YFp2vVMPVDOaYCOD1DShgS4XN $5 \mathrm{gb} 87 \mathrm{~B} 4 \mathrm{c} / \mathrm{r} 9 \mathrm{sE}+\mathrm{sAAAAAAAA} 2 \mathrm{CA}==$

\section{Conclusions}

Using high resolution mass spectrometry, we have identified the largest number of OA synovial fluid proteins reported thus far. Multiple fractionation methodologies were employed to decrease the complexity of the sample and increase the depth of our analysis. We have identified 545 proteins that were not previously reported in OA synovial fluid. We also validated the expression of
ANPEP, DKK3 and OGN in ten OA synovial fluid samples by MRM analysis. Some of these identified proteins can be further evaluated for their potential as specific targets or useful biomarkers for OA. These proteins could further enhance our knowledge and provide better insights regarding the underlying mechanism of $\mathrm{OA}$ pathogenesis perhaps leading to better therapeutic strategies.

\section{Methods}

\section{Sample collection and processing}

The samples were collected after obtaining informed consent of the patients and approval from the Institutional Ethical Committees of the Armed Forces Medical College, Pune, Fortis Hospitals, Bangalore and Command Air Force Hospital, Bangalore. Synovial fluid samples were collected from the affected joints of $10 \mathrm{OA}$ patients, clinically diagnosed as per the criteria of American College of Rheumatology. These 10 OA patients included 7 females and 3 males with an average age of 65 years. Approximately $5 \mathrm{ml}$ of synovial fluid was aspirated from each patient in heparin containing BD vacutainers (Becton, Dickinson and Company, New Jersey). The synovial fluid was then centrifuged at $1,500 \mathrm{~g}$ for 15 minutes and the supernatants were then filtered by using $0.22 \mu \mathrm{m}$ filters (Catalog number: SLGV033RS Millipore, Massachusetts, USA) and stored at $-80^{\circ} \mathrm{C}$ until further processing. Twelve $\mathrm{mg}$ of protein isolated from five OA synovial fluid samples was pooled and depleted using Human 6-Multiple Affinity Removal LC Column (MARS-6) (Agilent Technologies, Santa Clara, USA) as per manufacturer's instructions. The six most abundant proteins that are depleted using Human MARS-6 column are albumin, transferrin, haptoglobin, IgG, IgA, and alpha-1 antitrypsin. For each round of depletion, $1 \mathrm{mg}$ protein was loaded onto the column and 12 such depletion runs were carried out. The elution of proteins was monitored at $280 \mathrm{~nm}$. The depleted synovial fluid samples from each round were pooled and their protein concentration was estimated by Lowry's method [73]. Protein from the depleted and pooled protein sample was subsequently fractionated by SDS-PAGE at protein level and by, strong cation exchange (SCX) chromatography and pI-based OFFGEL electrophoresis at peptide level.

\section{SDS-PAGE and in-gel digestion}

$300 \mu \mathrm{g}$ of OA synovial fluid protein depleted of abundant proteins was resolved on a 10\% SDS-PAGE $(16 \mathrm{X} 18 \mathrm{~cm})$. The gel was then stained using colloidal Coomassie blue. Twenty eight gel bands were excised and destained using $40 \mathrm{mM}$ ammonium bicarbonate in $40 \%$ acetonitrile (ACN). In-gel digestion was carried out as described previously [74]. The sample was subjected 
Table 3 A list of peptides along with the transitions monitored for the proteins validated by MRM analysis

\begin{tabular}{|c|c|c|c|c|c|c|}
\hline Gene symbol & Protein name & Peptide sequence & Collision energy & Q1 & Q3 & lon type \\
\hline \multirow[t]{4}{*}{ ANPEP } & Alanyl (membrane) aminopeptidase & AQIINDAFNLASAHK & 30 & 806.93 & 887.47 & y8 \\
\hline & & & & & 740.40 & $y 7$ \\
\hline & & & & & 626.36 & y6 \\
\hline & & & & & 513.28 & y5 \\
\hline \multirow[t]{4}{*}{ ANPEP } & Alanyl (membrane) aminopeptidase & YLSYTLNPDLIR & 27.4 & 734.40 & 840.49 & $y 7$ \\
\hline & & & & & 727.41 & y6 \\
\hline & & & & & 613.37 & y5 \\
\hline & & & & & 516.31 & $\mathrm{y} 4$ \\
\hline \multirow[t]{4}{*}{ DKK3 } & Dickkopf WNT signaling pathway inhibitor 3 & DQDGEILLPR & 21.8 & 578.30 & 797.49 & $y 7$ \\
\hline & & & & & 740.47 & y6 \\
\hline & & & & & 611.42 & y5 \\
\hline & & & & & 498.34 & $\mathrm{y} 4$ \\
\hline \multirow[t]{4}{*}{ OGN } & Osteoglycin & DFADIPNLR & 20.1 & 530.77 & 798.45 & $y 7$ \\
\hline & & & & & 727.41 & y6 \\
\hline & & & & & 612.38 & y5 \\
\hline & & & & & 499.30 & $y 4$ \\
\hline \multirow[t]{4}{*}{ OGN } & Osteoglycin & LEGNPIVLGK & 19.7 & 520.31 & 797.49 & y8 \\
\hline & & & & & 740.47 & $y 7$ \\
\hline & & & & & 626.42 & y6 \\
\hline & & & & & 529.37 & y5 \\
\hline
\end{tabular}

to reduction using $5 \mathrm{mM}$ DTT $\left(60^{\circ} \mathrm{C}\right.$ for 45 minutes) followed by alkylation using $20 \mathrm{mM}$ iodoacetamide (room temperature for $10 \mathrm{~min}$ in dark). Trypsin digestion was carried out at $37^{\circ} \mathrm{C}$ for $12-16 \mathrm{hrs}$ (Catalog number: V5111 Sequencing grade, Promega, Madison, WI, US). Peptides were extracted from gel pieces sequentially using $0.4 \%$ formic acid in $3 \%$ ACN twice, once using $0.4 \%$ formic acid in $50 \% \mathrm{ACN}$ and once using $100 \%$ ACN. The extracted peptides were dried and stored at $-80^{\circ} \mathrm{C}$ until LC-MS/MS analysis.

\section{In-solution digestion}

Five hundred $\mu \mathrm{g}$ of depleted synovial fluid protein was reconstituted in $40 \mathrm{mM}$ ammonium bicarbonate. It was then reduced (5 mM DTT), alkylated (20 mM iodoacetamide) and digested overnight using trypsin as mentioned above.

\section{Strong cation exchange (SCX) chromatography}

SCX was carried out as described earlier [75]. Briefly, $200 \mu \mathrm{g}$ of digested peptide mixture was acidified using $1 \mathrm{M}$ phosphoric acid and equilibrated with $10 \mathrm{mM}$ potassium phosphate buffer containing 25\% acetonitrile, pH 2.85 (solvent A) and fractionated using SCX on a Polysulfoethyl A column (PolyLC, Columbia, MD) (300 ̊, $5 \mu \mathrm{m}, 100 \times 2.1 \mathrm{~mm}$ ) using an Agilent $1200 \mathrm{HPLC}$ system (Agilent Technologies, Santa Clara, USA) containing a binary pump, UV detector and a fraction collector. The peptides were eluted using a salt gradient (0 to 100\%) between solvent A and solvent B (10 mM potassium phosphate buffer containing $25 \%$ acetonitrile, $350 \mathrm{mM} \mathrm{KCl}$, $\mathrm{pH}$ 2.85). Twenty six fractions obtained from the fractionation were completely dried, reconstituted in $0.1 \%$ trifluoroacetic acid, and further desalted using stage-tips packed with C18 material [76]. Desalted fractions were dried in speedvac and reconstituted in $10 \mu \mathrm{l}$ of $0.1 \%$ TFA prior to reversed-phase (RP) liquid chromatography based tandem mass spectrometry (LC-MS/MS) analysis.

\section{OFFGEL fractionation}

Approximately $300 \mu \mathrm{g}$ of in-solution digested depleted tryptic peptides was used for isoelectric point based fractionation using Agilent's 3100 OFFGEL fractionator (Agilent Technologies, Santa Clara, USA). As per the manufacturer's protocol, peptides were separated using $\mathrm{pH}$ 3-10 IPG strip. The peptides were focused for $50 \mathrm{kVh}$ with maximum current of $50 \mu \mathrm{A}$ and maximum voltage set to $4000 \mathrm{~V}$. Twelve fractions were collected after fractionation and then acidified using 1\% TFA prior to sample cleaning using stage-tips [76].

\section{Lectin affinity enrichment}

Approximately $10 \mathrm{mg}$ of the total protein pooled from five OA samples was diluted in $10 \mathrm{mM}$ phosphate buffer, $\mathrm{pH}$ 7.8. For glycoprotein enrichment, the samples were 

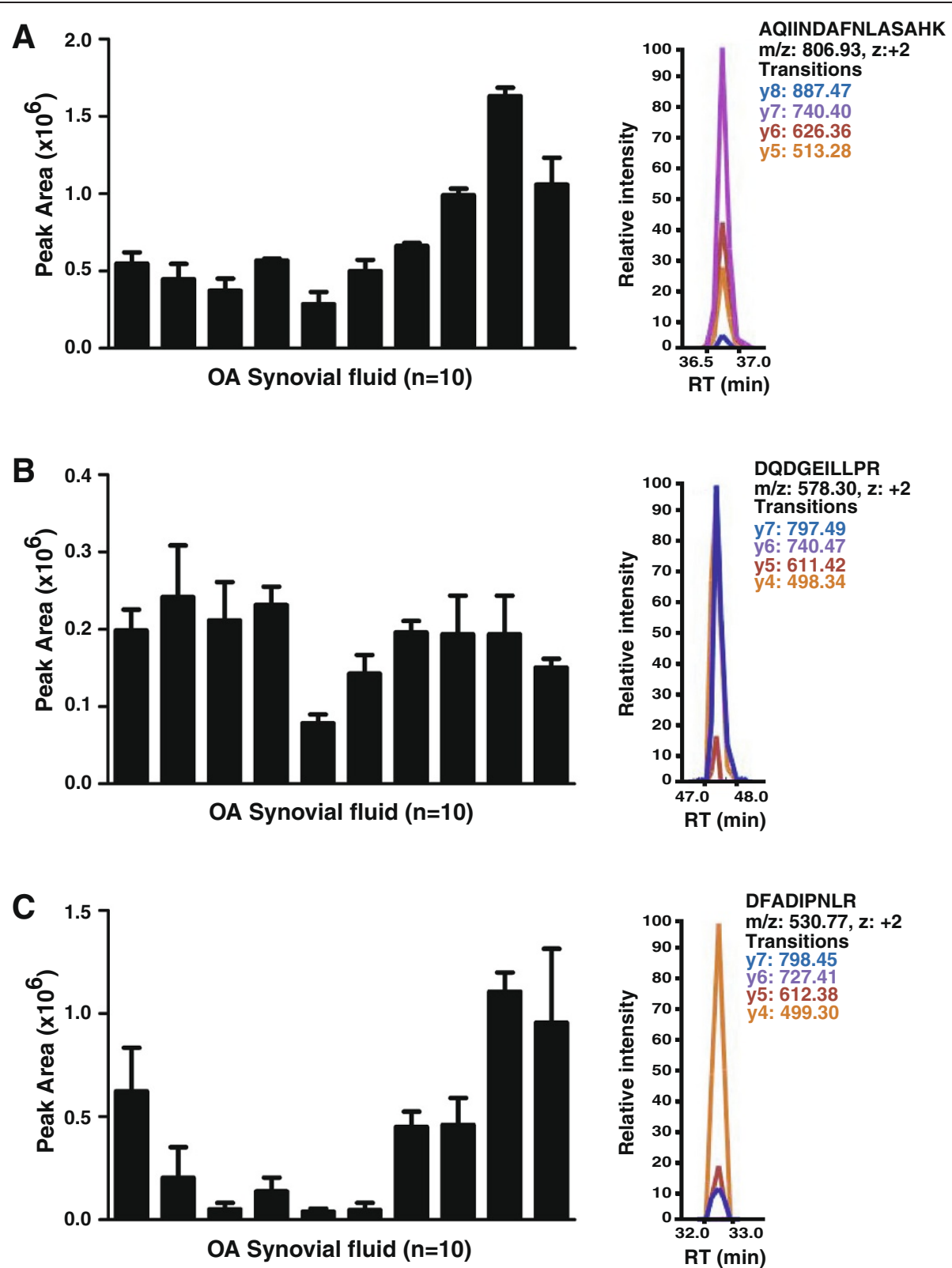

Figure 4 Validation of proteins identified in OA synovial fluid by MRM analysis. Bar graph representation of the peak area along with the MRM traces for the peptides validated by MRM. (A) Alanyl (membrane) aminopeptidase (ANPEP): AQIINDAFNLASAHK $(z=+2, m / z=806.93)$;

(B) Dickkopf WNT signaling pathway inhibitor 3 (DKK3): DQDGEILLPR ( $z=+2, \mathrm{~m} / \mathrm{z}=578.30)$; (C) Osteoglycin (OGN): DFADIPNLR $(\mathrm{z}=+2, \mathrm{~m} / \mathrm{z}=530.77)$. (OA synovial fluid $n=10$, RT: Retention time).

incubated with a mixture of three agarose conjugated lectins- concanavalin A (Con A), wheat germ agglutinin and jacalin (Vector labs, USA) for $12 \mathrm{~h}$ at $4^{\circ} \mathrm{C}$. The beads were then washed three times using wash buffer (10 mM phosphate buffer, $\mathrm{pH} 7.8$ ) and the bound proteins were eluted using a mixture of carbohydrates (100 mM each of $\mathrm{N}$-acetylglucosamine, melibiose and galactose). The eluate was dialyzed to remove free sugars and then concentrated using $3 \mathrm{kDa}$ cut-off filters. The protein concentration was estimated by Lowry's method. Two hundred and fifty $\mu \mathrm{g}$ of the enriched protein fraction was then resolved by SDS-PAGE. Twenty six gel bands were excised and subjected to in-gel trypsin digestion procedure as described in the previous section [74]. Two hundred and fifty $\mu \mathrm{g}$ of the enriched glycoprotein was also subjected to SCX fractionation as described earlier. Twenty fractions were collected and desalted using stage tips as mentioned above. 


\section{LC-MS/MS analysis}

Tandem mass spectrometric analysis of 112 fractions obtained from depleted total proteome and enriched glycoproteome was carried out using LTQ-Orbitrap Velos mass spectrometer (Thermo Scientific, Bremen, Germany) interfaced with Agilent 1200 (Agilent technologies, Santa Clara, CA, USA) nano liquid chromatography system. The LC system consisted of an enrichment column $(3 \mathrm{~cm} \times$ $75 \mu \mathrm{m}, \mathrm{C} 18$ material $5 \mu$ particle size, $100 \AA$ pore size) and an analytical column $(10 \mathrm{~cm} \times 75 \mu \mathrm{m}, \mathrm{C} 18$ material C18 material $5 \mu$ particle size, $100 \AA$ pore size) packed using pressure injection cell. Electrospray ionization source was fitted with an emitter tip $8 \mu \mathrm{m}$ (New Objective, Woburn, MA) and maintained at $2000 \mathrm{~V}$ ion spray voltage. Peptide samples were loaded onto an enrichment column in $0.1 \%$ formic acid, 5\% ACN for 15 min and peptide separation carried out using a linear gradient of $7-35 \%$ solvent $\mathrm{B}$ ( $90 \%$ ACN in $0.1 \%$ formic acid) for 60 minutes at a constant flow rate of $350 \mathrm{nl} / \mathrm{min}$. Data was acquired using Xcalibur 2.1 (Thermo Scientific, Bremen, Germany). The MS spectra were acquired in a data-dependent manner in the $\mathrm{m} / \mathrm{z}$ range of 350 to 1800 and survey scans were acquired in Orbitrap mass analyzer at a mass resolution of 60,000 at $400 \mathrm{~m} / \mathrm{z}$. The MS/MS data was acquired in Orbitrap mass analyzer at a resolution of 15,000 at $400 \mathrm{~m} / \mathrm{z}$ by targeting top 20 most abundant precursor ions for fragmentation using higher energy collisional dissociation activation at $39 \%$ normalised collision energy. Single and unassigned charge state precursor ions were rejected. The dynamic exclusion option was enabled during data acquisition with exclusion duration of 60 seconds. Lock mass option was enabled for real time calibration using polycyclodimethylsiloxane $(\mathrm{m} / \mathrm{z}$, 445.12) ions [77].

\section{Data analysis}

Mass spectrometry data was analyzed using multiple search engines to maximize the peptide identifications. Proteome Discoverer 1.3 (Thermo Scientific, Bremen, Germany) was used to carry out the peak list generation and database searches. Precursor mass range of 500 to $8,000 \mathrm{Da}$ and signal to noise ratio of 1.5 were used as the criteria for generation of peak list files. NCBI Refseq 49 human protein database with known contaminants (32,967 entries) was used as a reference database. Sequest and Mascot algorithms were used to carry out database searches. The parameters used for database searches include trypsin as a protease with allowed one missed cleavage, carbamidomethyl cysteine as a fixed modification, and oxidation of methionine as a dynamic modification. Precursor ion mass error window of $20 \mathrm{ppm}$ and fragment ion mass error window of $0.1 \mathrm{Da}$ were allowed. The raw data obtained were searched against decoy database to calculate $1 \%$ false discovery rate cut-off score [78]. Spectra that matched to the contaminants and those that did not pass the 1\% FDR threshold were not considered for analysis.

\section{Multiple reaction monitoring (MRM)}

MRM assays were developed to validate the results of LCMS/MS analysis for three target proteins. Skyline 2.1 was used for method development, data analysis and interpretation of the MRM results [79]. Proteotypic peptides for each protein were selected from the discovery LC-MS/MS experiments. Preference was given to proteotypic peptides with precursor charge +2 that did not contain cysteine or methionine. A minimum of four transitions were monitored for each peptide. Equal protein amounts from the individual OA synovial fluid samples were subjected to trypsin digestion as described earlier [10]. MRM of each sample was carried out in triplicates on TSQ Quantum Ultra (Thermo, San Jose, CA) interfaced with Easy nanoLC II (previously Proxeon, Thermo Scientific, Bremen, Germany). Peptides were enriched on a trap column $(5 \mu \mathrm{m}$, $75 \mu \mathrm{m} \times 2 \mathrm{~cm}$.) for 5 minutes with solvent A (5\% ACN in $0.1 \%$ formic acid). The peptides were separated on analytical column $(3 \mu \mathrm{m}, 75 \mu \mathrm{m} \times 10 \mathrm{~cm})$ with a linear gradient of $7-35 \%$ solvent $\mathrm{B}$ (95\% $\mathrm{ACN}$ in $0.1 \%$ formic acid) for $60 \mathrm{~min}$ at a constant flow rate of $300 \mathrm{nl} / \mathrm{min}$. Both columns were packed in-house using Magic C18 AQ (Michrom Bioresources). Spray voltage of $2.5 \mathrm{kV}$ was applied and ion transfer tube was maintained at $275^{\circ} \mathrm{C}$. MRM data was acquired with Q1 and Q3 set at resolution of 0.4 and 0.7 respectively. The collision energy for each transition was optimized in Skyline based on the preliminary results [80].

\section{Determination of the relative abundance of OA synovial fluid proteins}

The relative abundance of proteins in OA synovial fluid was determined by calculating normalized spectral abundance factors (NSAF) for each protein identified in the study as previously described [81]. NSAF for a protein $\mathrm{k}$ was calculated by dividing the total number of peptide spectral matches $(S)$ identified for protein $k$ by protein length (L) and then divided by the sum of S/L ratio for all proteins.

\section{Bioinformatics analysis}

Gene Ontology (GO) [82] analysis was done to identify the biological processes and the molecular function associated with the identified proteins. Subcellular localization, post-translational modifications, transmembrane domain and signal peptide information of the identified proteins were obtained from Human Protein Reference Database (HPRD) (http://www.hprd.org), which is a GO compliant database [22,23]. 


\section{Additional files}

Additional file 1: Summary of proteins identified from OA synovial fluid by using different fractionation methods. (A) Venn diagram illustrating the number of proteins identified from depleted fraction using three different fractionation methods (SDS-PAGE, SCX, and OFFGEL). (B) Venn diagram illustrating the number of proteins identified from lectin enriched fraction subjected to SDS-PAGE and SCX fractionation.

Additional file 2: A list of proteins identified in this study. This table lists all the synovial fluid proteins identified in the study along with the protein accession, gene symbol, protein description, coverage, unique peptides, number of peptide spectral matches (PSMs), amino acids, relative abundance, molecular weight and molecular function.

Additional file 3: A complete list of peptides identified in this study. This table contains all the peptides identified in the study along with peptide sequence, protein description, gene symbol, protein group accession, XCorr, Ion Score, modifications, charge, m/z (Da), MH + (Da), Delta mass (ppm) and retention time (RT).

Additional file 4: Relative abundance of twenty five most abundant proteins in OA synovial fluid.

\section{Additional file 5: A list of proteins identified by lectin affinity} enrichment. This table includes a list of all the proteins identified by lectin affinity enrichment along with protein accession, gene symbol, protein description and post-translational modifications obtained from HPRD.

\section{Abbreviations}

OA: Osteoarthritis; MARS: Multiple affinity removal system; GO: Gene ontology; ECM: Extracellular matrix; OGN: Osteoglycin; OMD: Osteomodulin; ASPN: Asporin

\section{Competing interests}

The authors declare that they have no competing interests.

\section{Authors' contributions}

AP, SS, SM and HG participated in the conception and study design. LB and MB collected the samples and performed the experiments. RSN, SA, SR and DSK carried out fractionation and mass spectrometry analysis of the samples. LB wrote the manuscript. LB and YS prepared the manuscript figures. LB, NS, $S M S, J K T, R R, R G$ were involved in data analysis and interpretation. MD, NK, SGT, W, NS edited the manuscript. RJ, YLR, TSKP, HG, SM and AP critically read and revised the manuscript. All authors read and approved the final manuscript.

\section{Acknowledgements}

We thank the Department of Biotechnology, Government of India for research support to the Institute of Bioinformatics, Bangalore. We thank Agilent Technologies and Thermo Scientific for the instrument support. Raja Sekhar Nirujogi is a recipient of Senior Research Fellowship award from Council of Scientific and Industrial Research (CSIR), Government of India. Sartaj Ahmad is a recipient of Junior Research Fellowship from University Grants Commission (UGC), Government of India. Srikanth Srinivas Manda. Santosh Renuse and Dhanashree S. Kelkar are recipients of Senior Research Fellowship award from the University Grants Commission (UGC), Government of India. Harsha Gowda is a Wellcome Trust/DBT India Alliance Early Career Fellow.

\section{Author details}

${ }^{1}$ Institute of Bioinformatics, International Technology Park, Bangalore, Karnataka 560066, India. '2Department of Biotechnology, Kuvempu University, Shankaraghatta, Shimoga, Karnataka 577451, India. ${ }^{3}$ Centre for Excellence in Bioinformatics, School of Life Sciences, Pondicherry University, Pondicherry, Puducherry 605014, India. "Manipal University, Madhava Nagar, Manipal, Karnataka 576104, India. ${ }^{5}$ Amrita School of Biotechnology, Amrita University, Kollam, Kerala 690525, India. ${ }^{6}$ Rajiv Gandhi University of Health Sciences, Bangalore, Karnataka 560041, India. ${ }^{7}$ Department of Internal Medicine, Armed Forces Medical College, Pune, Maharashtra 411040, India. ${ }^{8}$ Department of Rheumatology, Fortis Hospitals, Bangalore, Karnataka 560076, India.
${ }^{9}$ Department of Rheumatology, Command Airforce Hospital, Bangalore 560008, India. ${ }^{10}$ Laboratory for Integrated Bioinformatics, RIKEN Center for Integrative Medical Sciences (IMS-RCAI), Yokohama Institute, Yokohama, Kanagawa 230-0045, Japan. ${ }^{11}$ McKusick-Nathans Institute of Genetic Medicine, Johns Hopkins University, 733 N. Broadway, BRB 527, Baltimore, MD 21205, USA. ${ }^{12}$ Department of Oncology, Johns Hopkins University School of Medicine, Baltimore, MD 21205, USA. ${ }^{13}$ Department of Pathology, Johns Hopkins University School of Medicine, Baltimore MD 21205, USA.

${ }^{14}$ Biological Chemistry, Johns Hopkins University School of Medicine, Baltimore, MD 21205, USA.

Received: 6 August 2013 Accepted: 6 January 2014

Published: 17 February 2014

\section{References}

1. Goldring SR, Goldring MB: Clinical aspects, pathology and pathophysiology of osteoarthritis. J Musculoskelet Neuronal Interact 2006, 6:376-378.

2. Rousseau JC, Delmas PD: Biological markers in osteoarthritis. Nat Clin Pract Rheumatol 2007, 3:346-356

3. Gobezie R, Kho A, Krastins B, Sarracino DA, Thornhill TS, Chase M, Millett PJ, Lee DM: High abundance synovial fluid proteome: distinct profiles in health and osteoarthritis. Arthritis Res Ther 2007, 9:R36.

4. Longo D, Fauci A, Kasper D, Hauser S, Jameson J, Loscalzo J: Harrison's Principles of Internal Medicine. 18th edition. New York: Mcgraw-hill; 2011.

5. Bhattacharyya T, Gale D, Dewire P, Totterman S, Gale ME, McLaughlin S, Einhorn TA, Felson DT: The clinical importance of meniscal tears demonstrated by magnetic resonance imaging in osteoarthritis of the knee. J Bone Joint Surg Am 2003, 85-A:4-9.

6. De Ceuninck F, Berenbaum F: Proteomics: addressing the challenges of osteoarthritis. Drug Discov Today 2009, 14:661-667.

7. Ruiz-Romero C, Blanco FJ: Proteomics role in the search for improved diagnosis, prognosis and treatment of osteoarthritis. Osteoarthritis Cartilage 2010, 18:500-509.

8. Hui AY, McCarty WJ, Masuda K, Firestein GS, Sah RL: A systems biology approach to synovial joint lubrication in health, injury, and disease. Wiley Interdiscip Rev Syst Biol Med 2012, 4:15-37.

9. Adachi J, Kumar C, Zhang Y, Olsen JV, Mann M: The human urinary proteome contains more than 1500 proteins, including a large proportion of membrane proteins. Genome Biol 2006, 7:R80.

10. Barbhuiya MA, Sahasrabuddhe NA, Pinto SM, Muthusamy B, Singh TD, Nanjappa V, Keerthikumar S, Delanghe B, Harsha HC, Chaerkady R, Jalaj V Gupta S, Shrivastav BR, Tiwari PK, Pandey A: Comprehensive proteomic analysis of human bile. Proteomics 2011, 11:4443-4453.

11. de Souza GA, Godoy LM, Mann M: Identification of 491 proteins in the tear fluid proteome reveals a large number of proteases and protease inhibitors. Genome Biol 2006, 7:R72.

12. Liu T, Qian WJ, Gritsenko MA, Xiao W, Moldawer LL, Kaushal A, Monroe ME, Varnum SM, Moore RJ, Purvine SO, Maier RV, Davis RW, Tompkins RG, Camp DG 2nd, Smith RD, Inflammation and the Host Response to Injury Large Scale Collaborative Research Programm: High dynamic range characterization of the trauma patient plasma proteome. Mol Cell Proteomics 2006, 5:1899-1913.

13. Marimuthu A, O'Meally RN, Chaerkady R, Subbannayya $Y$, Nanjappa $V$, Kumar P, Kelkar DS, Pinto SM, Sharma R, Renuse S, Goel R, Christopher R, Delanghe B, Cole RN, Harsha HC, Pandey A: A comprehensive map of the human urinary proteome. J Proteome Res 2011, 10:2734-2743.

14. Molina H, Bunkenborg J, Reddy GH, Muthusamy B, Scheel PJ, Pandey A: A proteomic analysis of human hemodialysis fluid. Mol Cell Proteomics 2005, 4:637-650.

15. Pilch B, Mann M: Large-scale and high-confidence proteomic analysis of human seminal plasma. Genome Biol 2006, 7:R40.

16. Yamagiwa H, Sarkar G, Charlesworth MC, McCormick DJ, Bolander ME: Two-dimensional gel electrophoresis of synovial fluid: method for detecting candidate protein markers for osteoarthritis. J Orthop Sci 2003, 8:482-490.

17. Kamphorst JJ, van der Heijden R, DeGroot J, Lafeber FP, Reijmers TH, van El B, Tjaden UR, van der Greef J, Hankemeier T: Profiling of endogenous peptides in human synovial fluid by NanoLC-MS: method validation and peptide identification. J Proteome Res 2007, 6:4388-4396.

18. Wang Q, Rozelle AL, Lepus CM, Scanzello CR, Song JJ, Larsen DM, Crish JF, Bebek G, Ritter SY, Lindstrom TM, Hwang I, Wong HH, Punzi L, Encarnacion 
A, Shamloo M, Goodman SB, Wyss-Coray T, Goldring SR, Banda NK, Thurman JM, Gobezie R, Crow MK, Holers VM, Lee DM, Robinson WH: Identification of a central role for complement in osteoarthritis. Nat Med 2011, 17:1674-1679.

19. Sohn DH, Sokolove J, Sharpe O, Erhart JC, Chandra PE, Lahey LJ, Lindstrom TM, Hwang I, Boyer KA, Andriacchi TP, Robinson WH: Plasma proteins present in osteoarthritic synovial fluid can stimulate cytokine production via Toll-like receptor 4. Arthritis Res Ther 2012, 14:R7.

20. Ritter SY, Subbaiah R, Bebek G, Crish J, Scanzello CR, Krastins B, Sarracino D, Lopez MF, Crow MK, Aigner T, Goldring MB, Goldring SR, Lee DM, Gobezie $\mathrm{R}$, Aliprantis AO: Proteomic analysis of synovial fluid from the osteoarthritic knee: comparison with transcriptome analyses of joint tissues. Arthritis Rheum 2013, 65:981-992.

21. de Seny D, Sharif M, Fillet M, Cobraiville G, Meuwis MA, Marée R, Hauzeur JP, Wehenkel L, Louis E, Merville MP, Kirwan J, Ribbens C, Malaise M: Discovery and biochemical characterisation of four novel biomarkers for osteoarthritis. Ann Rheum Dis 2011, 70:1144-1152.

22. Keshava Prasad TS, Goel R, Kandasamy K, Keerthikumar S, Kumar S, Mathivanan S, Telikicherla D, Raju R, Shafreen B, Venugopal A, Balakrishnan L, Marimuthu A, Banerjee S, Somanathan DS, Sebastian A, Rani S, Ray S, Harrys Kishore CJ, Kanth S, Ahmed M, Kashyap MK, Mohmood R, Ramachandra YL, Krishna V, Rahiman BA, Mohan S, Ranganathan P, Ramabadran S, Chaerkady R, Pandey A: Human Protein Reference Database-2009 update. Nucleic Acids Res 2009, 37:D767-772.

23. Prasad TS, Kandasamy K, Pandey A: Human Protein Reference Database and Human Proteinpedia as discovery tools for systems biology. Methods Mol Biol 2009, 577:67-79

24. Martel-Pelletier J, Boileau C, Pelletier JP, Roughley PJ: Cartilage in normal and osteoarthritis conditions. Best Pract Res Clin Rheumatol 2008, 22:351-384

25. Kiani C, Chen L, Wu YJ, Yee AJ, Yang BB: Structure and function of aggrecan. Cell Res 2002, 12:19-32.

26. El-Arman MM, El-Fayoumi G, El-Shal E, El-Boghdady I, El-Ghaweet A: Aggrecan and cartilage oligomeric matrix protein in serum and synovial fluid of patients with knee osteoarthritis. Hss J 2010, 6:171-176.

27. Li H, Wang D, Wu ZQ, Zhong JM, Yuan YJ: Serum levels of cartilage oligomeric matrix protein in the diagnosis of knee osteoarthritis. Zhongguo Gu Shang 2012, 25:380-383.

28. Xie DL, Meyers R, Homandberg GA: Fibronectin fragments in osteoarthritic synovial fluid. J Rheumatol 1992, 19:1448-1452.

29. Tchetverikov I, Lohmander LS, Verzijl N, Huizinga TW, TeKoppele JM, Hanemaaijer R, DeGroot J: MMP protein and activity levels in synovial fluid from patients with joint injury, inflammatory arthritis, and osteoarthritis. Ann Rheum Dis 2005, 64:694-698.

30. Neu CP, Reddi AH, Komvopoulos K, Schmid TM, Di Cesare PE: Increased friction coefficient and superficial zone protein expression in patients with advanced osteoarthritis. Arthritis Rheum 2010, 62:2680-2687.

31. Hunter DJ, Felson DT: Osteoarthritis. BMJ 2006, 332:639-642.

32. Lorenzo P, Aspberg A, Onnerfjord P, Bayliss MT, Neame PJ, Heinegard D: Identification and characterization of asporin. a novel member of the leucine-rich repeat protein family closely related to decorin and biglycan. J Biol Chem 2001, 276:12201-12211.

33. Sakao K, Takahashi KA, Arai Y, Saito M, Honjyo K, Hiraoka N, Kishida T, Mazda O, Imanishi J, Kubo T: Asporin and transforming growth factor-beta gene expression in osteoblasts from subchondral bone and osteophytes in osteoarthritis. J Orthop Sci 2009, 14:738-747

34. Duval E, Bigot N, Hervieu M, Kou I, Leclerca S, Galera P, Boumediene K, Bauge $C$ : Asporin expression is highly regulated in human chondrocytes. Mol Med 2011, 17:816-823.

35. Kalamajski S, Aspberg A, Lindblom K, Heinegard D, Oldberg A: Asporin competes with decorin for collagen binding, binds calcium and promotes osteoblast collagen mineralization. Biochem J 2009, 423:53-59.

36. Kizawa H, Kou I, lida A, Sudo A, Miyamoto Y, Fukuda A, Mabuchi A, Kotani A, Kawakami A, Yamamoto S, Uchida A, Nakamura K, Notoya K, Nakamura Y, Ikegawa S: An aspartic acid repeat polymorphism in asporin inhibits chondrogenesis and increases susceptibility to osteoarthritis. Nat Genet 2005, 37:138-144.

37. Nakajima M, Kizawa H, Saitoh M, Kou I, Miyazono K, Ikegawa S: Mechanisms for asporin function and regulation in articular cartilage. $J$ Biol Chem 2007, 282:32185-32192.
38. Kohfeldt E, Sasaki T, Gohring W, Timpl R: Nidogen-2: a new basement membrane protein with diverse binding properties. J Mol Biol 1998, 282:99-109

39. Kruegel J, Sadowski B, Miosge N: Nidogen-1 and nidogen-2 in healthy human cartilage and in late-stage osteoarthritis cartilage. Arthritis Rheum 2008, 58:1422-1432.

40. Shapiro LH, Ashmun RA, Roberts WM, Look AT: Separate promoters control transcription of the human aminopeptidase $\mathrm{N}$ gene in myeloid and intestinal epithelial cells. J Biol Chem 1991, 266:11999-12007.

41. Fukasawa K, Fujii H, Saitoh Y, Koizumi K, Aozuka Y, Sekine K, Yamada M, Saiki I, Nishikawa K: Aminopeptidase N (APN/CD13) is selectively expressed in vascular endothelial cells and plays multiple roles in angiogenesis. Cancer Lett 2006, 243:135-143.

42. Lendeckel U, Arndt M, Bukowska A, Tadje J, Wolke C, Kahne T, Neubert K, Faust J, Ittenson A, Ansorge S, Reinhold D: Synergistic action of DPIV and APN in the regulation of T cell function. Adv Exp Med Biol 2003, 524:123-131.

43. Mina-Osorio P, Winnicka B, O'Conor C, Grant CL, Vogel LK, Rodriguez-Pinto $D$, Holmes KV, Ortega E, Shapiro LH: CD13 is a novel mediator of monocytic/endothelial cell adhesion. J Leukoc Biol 2008, 84:448-459.

44. Bates EE, Fridman WH, Mueller CG: The ADAMDEC1 (decysin) gene structure: evolution by duplication in a metalloprotease gene cluster on chromosome 8p12. Immunogenetics 2002, 54:96-105.

45. Fritsche J, Muller A, Hausmann M, Rogler G, Andreesen R, Kreutz M: Inverse regulation of the ADAM-family members, decysin and MADDAM/ADAM19 during monocyte differentiation. Immunology 2003, 110:450-457.

46. Hu B, Coulson L, Moyer B, Price PA: Isolation and molecular cloning of a novel bone phosphoprotein related in sequence to the cystatin family of thiol protease inhibitors. J Biol Chem 1995, 270:431-436.

47. Price PA, Nguyen TM, Williamson MK: Biochemical characterization of the serum fetuin-mineral complex. J Biol Chem 2003, 278:22153-22160.

48. Brochmann EJ, Simon RJ, Jawien J, Behnam K, Sintuu C, Wang JC, Murray SS: Carboxy terminus of secreted phosphoprotein-24 kDa (spp24) is essential for full inhibition of BMP-2 activity. J Orthop Res 2010, 28:1200-1207.

49. Sintuu C, Murray SS, Behnam K, Simon R, Jawien J, Silva JD, Duarte ME, Brochmann EJ: Full-length bovine spp24 [spp24 (24-203)] inhibits BMP-2 induced bone formation. J Orthop Res 2008, 26:753-758.

50. Agarwal SK, Brenner MB: Role of adhesion molecules in synovial inflammation. Curr Opin Rheumatol 2006, 18:268-276.

51. Shur I, Socher R, Hameiri M, Fried A, Benayahu D: Molecular and cellular characterization of SEL-OB/SVEP1 in osteogenic cells in vivo and in vitro. J Cell Physiol 2006, 206:420-427.

52. Sato-Nishiuchi R, Nakano I, Ozawa A, Sato Y, Takeichi M, Kiyozumi D, Yamazaki K, Yasunaga T, Futaki S, Sekiguchi K: Polydom/SVEP1 is a ligand for integrin alpha9beta1. J Biol Chem 2012, 287:25615-25630.

53. Sommarin $Y$, Wendel M, Shen Z, Hellman U, Heinegard D: Osteoadherin, a cell-binding keratan sulfate proteoglycan in bone, belongs to the family of leucine-rich repeat proteins of the extracellular matrix. J Biol Chem 1998, 273:16723-16729.

54. Buchaille R, Couble ML, Magloire H, Bleicher F: Expression of the small leucine-rich proteoglycan osteoadherin/osteomodulin in human dental pulp and developing rat teeth. Bone 2000, 27:265-270.

55. Rehn AP, Cerny R, Sugars RV, Kaukua N, Wendel M: Osteoadherin is upregulated by mature osteoblasts and enhances their in vitro differentiation and mineralization. Calcif Tissue Int 2008, 82:454-464.

56. Balint E, Lapointe D, Drissi H, van der Meijden C, Young DW, van Wijnen AJ, Stein JL, Stein GS, Lian JB: Phenotype discovery by gene expression profiling: mapping of biological processes linked to BMP-2-mediated osteoblast differentiation. J Cell Biochem 2003, 89:401-426.

57. Ducy P, Desbois C, Boyce B, Pinero G, Story B, Dunstan C, Smith E, Bonadio J, Goldstein S, Gundberg C, Bradley A, Karsenty G: Increased bone formation in osteocalcin-deficient mice. Nature 1996, 382:448-452.

58. Hamajima S, Hiratsuka K, Kiyama-Kishikawa M, Tagawa T, Kawahara M, Ohta M, Sasahara H, Abiko Y: Effect of low-level laser irradiation on osteoglycin gene expression in osteoblasts. Lasers Med Sci 2003, 18:78-82.

59. Balint G, Barabas K, Zeitler Z, Bakos J, Kekesi KA, Pethes A, Nagy E, Lakatos T, Balint PV, Szekanecz Z: Ex vivo soft-laser treatment inhibits the synovial expression of vimentin and alpha-enolase, potential autoantigens in rheumatoid arthritis. Phys Ther 2011, 91:665-674.

60. Zhu Y, Xu G, Patel A, McLaughlin MM, Silverman C, Knecht K, Sweitzer S, Li X, McDonnell P, Mirabile R, Zimmerman D, Boyce R, Tierney LA, Hu E, Livi GP, Wolf B, Abdel-Meguid SS, Rose GD, Aurora R, Hensley P, Briggs M, 
Young PR: Cloning, expression, and initial characterization of a novel cytokine-like gene family. Genomics 2002, 80:144-150.

61. Zhang LS, Hu HG, Liu YJ, Li J, Yu P, Zhang F, Yang TL, Tian Q, Zheng YP, Guo Y, Deng HW: A follow-up association study of two genetic variants for bone mineral density variation in Caucasians. Osteoporos Int 2012, 23:1867-1875

62. Zheng HF, Tobias JH, Duncan E, Evans DM, Eriksson J, Paternoster L, YergesArmstrong LM, Lehtimäki T, Bergström U, Kähönen M, Leo PJ, Raitakari O, Laaksonen M, Nicholson GC, Viikari J, Ladouceur M, Lyytikäinen LP, MedinaGomez C, Rivadeneira F, Prince RL, Sievanen H, Leslie WD, Mellström D, Eisman JA, Movérare-Skrtic S, Goltzman D, Hanley DA, Jones G, St Pourcain B, Xiao Y, Timpson NJ, Smith GD, Reid IR, Ring SM, Sambrook PN, Karlsson M, Dennison EM, Kemp JP, Danoy P, Sayers A, Wilson SG, Nethander M, McCloskey E, Vandenput L, Eastell R, Liu J, Spector T, Mitchell BD, Streeten EA, Brommage R, Pettersson-Kymmer U, Brown MA, Ohlsson C, Richards JB, Lorentzon M: WNT16 influences bone mineral density, cortical bone thickness, bone strength, and osteoporotic fracture risk. PLoS Genet 2012, 8:e1002745.

63. Hwang HJ, Quinn T, Zhang J: Identification of glycoproteins in human cerebrospinal fluid. Methods Mol Biol 2009, 566:263-276.

64. Jerkovic L, Voegele AF, Chwatal S, Kronenberg F, Radcliffe CM, Wormald MR, Lobentanz EM, Ezeh B, Eller P, Dejori N, Dieplinger B, Lottspeich F, Sattler W, Uhr M, Mechtler K, Dwek RA, Rudd PM, Baier G, Dieplinger H: Afamin is a novel human vitamin E-binding glycoprotein characterization and in vitro expression. J Proteome Res 2005, 4:889-899.

65. Kim BJ, Lee YS, Lee SY, Park SY, Dieplinger H, Ryu SH, Yea K, Choi S, Lee SH, Koh JM, Kim GS: Afamin secreted from nonresorbing osteoclasts acts as a chemokine for preosteoblasts via the Akt-signaling pathway. Bone 2012, 51:431-440

66. Cattano NM, Driban JB, Balasubramanian E, Barbe MF, Amin M, Sitler MR: Biochemical comparison of osteoarthritic knees with and without effusion. BMC Musculoskelet Disord 2011, 12:273.

67. Nielsen BB, Kastrup JS, Rasmussen H, Holtet TL, Graversen JH, Etzerodt M, Thogersen HC, Larsen IK: Crystal structure of tetranectin, a trimeric plasminogen-binding protein with an alpha-helical coiled coil. FEBS Lett 1997, 412:388-396.

68. Karlsson C, Dehne T, Lindahl A, Brittberg M, Pruss A, Sittinger M, Ringe J: Genome-wide expression profiling reveals new candidate genes associated with osteoarthritis. Osteoarthritis Cartilage 2010, 18:581-592.

69. Loeser RF, Olex AL, McNulty MA, Carlson CS, Callahan MF, Ferguson CM, Chou J, Leng X, Fetrow JS: Microarray analysis reveals age-related differences in gene expression during the development of osteoarthritis in mice. Arthritis Rheum 2012, 64:705-717.

70. Xiao SM, Gao Y, Cheung CL, Bow CH, Lau KS, Sham PC, Tan KC, Kung AW: Association of CDX1 binding site of periostin gene with bone mineral density and vertebral fracture risk. Osteoporos Int 2012, 23:1877-1887.

71. Meng J, Ma X, Ma D, Xu C: Microarray analysis of differential gene expression in temporomandibular joint condylar cartilage after experimentally induced osteoarthritis. Osteoarthritis Cartilage 2005, 13:1115-1125.

72. Kandasamy K, Keerthikumar S, Goel R, Mathivanan S, Patankar N, Shafreen B, Renuse S, Pawar H, Ramachandra YL, Acharya PK, Ranganathan P, Chaerkady R, Keshava Prasad TS, Pandey A: Human Proteinpedia: a unified discovery resource for proteomics research. Nucleic Acids Res 2009, 37:D773-781.

73. Lowry OH, Rosebrough NJ, Farr AL, Randall RJ: Protein measurement with the Folin phenol reagent. J Biol Chem 1951, 193:265-275.

74. Harsha HC, Molina H, Pandey A: Quantitative proteomics using stable isotope labeling with amino acids in cell culture. Nat Protoc 2008, 3:505-516.

75. Chaerkady R, Harsha HC, Nalli A, Gucek M, Vivekanandan P, Akhtar J, Cole RN, Simmers J, Schulick RD, Singh S, Torbenson M, Pandey A, Thuluvath PJ: A quantitative proteomic approach for identification of potential biomarkers in hepatocellular carcinoma. J Proteome Res 2008, 7:4289-4298.

76. Rappsilber J, Mann M, Ishihama Y: Protocol for micro-purification, enrichment, pre-fractionation and storage of peptides for proteomics using StageTips. Nat Protoc 2007, 2:1896-1906.

77. Olsen JV, de Godoy LM, Li G, Macek B, Mortensen P, Pesch R, Makarov A, Lange $\mathrm{O}$, Horning S, Mann M: Parts per million mass accuracy on an Orbitrap mass spectrometer via lock mass injection into a C-trap. Mol Cell Proteomics 2005, 4:2010-2021.
78. Kandasamy K, Pandey A, Molina H: Evaluation of several MS/MS search algorithms for analysis of spectra derived from electron transfer dissociation experiments. Anal Chem 2009, 81:7170-7180.

79. MacLean B, Tomazela DM, Shulman N, Chambers M, Finney GL, Frewen B, Kern R, Tabb DL, Liebler DC, MacCoss MJ: Skyline: an open source document editor for creating and analyzing targeted proteomics experiments. Bioinformatics 2010, 26:966-968.

80. Holstein Sherwood CA, Gafken PR, Martin DB: Collision energy optimization of $\mathrm{b}$ - and $\mathrm{y}$-ions for multiple reaction monitoring mass spectrometry. J Proteome Res 2011, 10:231-240.

81. Paoletti AC, Parmely TJ, Tomomori-Sato C, Sato S, Zhu D, Conaway RC, Conaway JW, Florens L, Washburn MP: Quantitative proteomic analysis of distinct mammalian Mediator complexes using normalized spectral abundance factors. Proc Natl Acad Sci U S A 2006, 103:18928-18933.

82. Ashburner M, Ball CA, Blake JA, Botstein D, Butler H, Cherry JM, Davis AP, Dolinski K, Dwight SS, Eppig JT, Harris MA, Hill DP, Issel-Tarver L, Kasarskis A, Lewis S, Matese JC, Richardson JE, Ringwald M, Rubin GM, Sherlock G: Gene ontology: tool for the unification of biology. The Gene Ontology Consortium. Nat Genet 2000, 25:25-29.

doi:10.1186/1559-0275-11-6

Cite this article as: Balakrishnan et al:: Proteomic analysis of human osteoarthritis synovial fluid. Clinical Proteomics 2014 11:6.

\section{Submit your next manuscript to BioMed Central and take full advantage of:}

- Convenient online submission

- Thorough peer review

- No space constraints or color figure charges

- Immediate publication on acceptance

- Inclusion in PubMed, CAS, Scopus and Google Scholar

- Research which is freely available for redistribution 